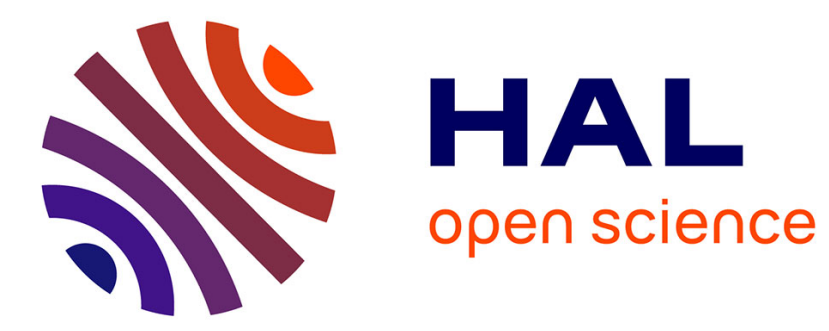

\title{
Coping with scarcity: The construction of the water conservation imperative in newspapers (1999-2018)
}

\author{
Anne-Lise Boyer, Yves-François Le Lay, Pascal Marty
}

\section{To cite this version:}

Anne-Lise Boyer, Yves-François Le Lay, Pascal Marty. Coping with scarcity: The construction of the water conservation imperative in newspapers (1999-2018). Global Environmental Change, 2021, 71, pp.102387. 10.1016/j.gloenvcha.2021.102387 . halshs-03500072

\section{HAL Id: halshs-03500072 \\ https://shs.hal.science/halshs-03500072}

Submitted on 17 Jan 2022

HAL is a multi-disciplinary open access archive for the deposit and dissemination of scientific research documents, whether they are published or not. The documents may come from teaching and research institutions in France or abroad, or from public or private research centers.
L'archive ouverte pluridisciplinaire HAL, est destinée au dépôt et à la diffusion de documents scientifiques de niveau recherche, publiés ou non, émanant des établissements d'enseignement et de recherche français ou étrangers, des laboratoires publics ou privés. 


\title{
Coping with scarcity: the construction of the water conservation imperative in newspapers (1999-2018)
}

Global Environmental Change 71 (2021) 102387

Anne-Lise Boyer, UMR 5600 EVS, 15 Parvis René Descartes, BP 7000, 69342 Lyon CEDEX 07

Yves-François Le Lay, Department of Geography, ENS de Lyon, UMR 5600 EVS, 15 Parvis

René Descartes, BP 700069342 Lyon CEDEX 07, France

Pascal Marty, USR 3129/UMIFRE 11 Maison Française d'Oxford, 2-10 Norham Road, Oxford OX2 6SE, London, UK

\section{Highlights}

- We analyze the success story of water conservation as a drought mitigation tool.

- We conduct a quantitative textual analysis of press articles published in Arizona.

- The press supports water conservation as the main adaptation strategy to water scarcity.

- Water conservation is framed as a non-mandatory imperative and as a new lifestyle.

- It operates as a consensual solution for the future of urbanization in arid lands.

\begin{abstract}
As water-stressed areas are expanding worldwide due to climate change, water conservation has become an important tool for managing water resources in drought contexts. Within a political ecology framework, our research questions the success story of water conservation. To do so, we conducted a quantitative textual analysis of 520 daily local press articles dealing with drought and water issues in Phoenix and Tucson (Arizona, USA). Using two lexicometric software, our analysis traces the rise of the water conservation narrative in the press. Our results show how newspapers can become an instrument of public policies to work towards their social acceptance. Moreover, water conservation is framed as a consensual tool. It reassures that threats associated with water scarcity will be successfully managed to sustain urban growth in arid regions. In this sense, water conservation operates following a logic of fix, in line with the successive hydrosocial fixes that helped the development of arid lands and does not question inherited power structures in water management.
\end{abstract}

Keywords: water scarcity; water conservation; newspapers; discourse; political ecology 
According to the World Meteorological Organization (2016; 2020), on a global scale, the part of lands affected by severe droughts has doubled between the 1970s and 2000, and five times as many territories could experience extreme droughts in 2050. Scientists thus predict an increase in aridity: on one hand, in the drylands, the water deficit is worsening; on the other hand, the arid climate zone tends to expand and could cover half of the Earth's surface by the end of the 21st century (Huang et al., 2017). By 2050, with a global climate warming of $1.5^{\circ} \mathrm{C}, 178$ million people are projected to live in drylands highly vulnerable to water stress and intense droughts (IPCC, 2020).

In this context, multiple studies have questioned how droughts are represented in the media, and especially in newspapers (Changnon and Easterling, 1989; Haughton, 1998; Degaetano, 1999; Sonnett et al., 2006; Tänzler et al., 2008; Bell, 2009; Paneque Salgado and Vargas Molina, 2015; Madruga de Brito et al., 2020). The press continues to play a key role in informing the general public about environmental issues (Boykoff and Boykoff, 2007; Boykoff, 2009; Bohensky and Leitch, 2014; Comby et al., 2014). Indeed, if we consider risks communication (Wakefield and Elliott, 2003), drought raises a particular challenge as it is a slow onset hazard that does not necessarily attract the direct attention of event-oriented media (Wilkins and Patterson, 1990; Sonnett et al., 2006), but also because it is the object of competing definitions (Whilhite and Glantz, 1985; Lloyd-Hughes, 2013; Wilhite and Pulwarty, 2017). Because of competing understandings of drought - an event diffused in time and space that affects different types of nonhuman (i.e., meteorological, hydrological, agricultural, and ecological drought) and human (i.e., socioeconomic drought) actors with different levels of intensity-, it is of utmost importance to understand the discursive and thus the socio-cultural context in which meaning is given to this phenomenon (Greene, 2021).

To discuss how newspapers shape the definition of drought and display the problems that drought represents, many scholars have adopted a Foucaldian approach (Foucault, 1972; 1980) focusing on the politics of environmental discourses (Hajer, 1995; Dryzek, 1997) and inspired by the critical discourse analysis (Fairclough, 2001; Richardson, 2007). This approach considers discourses as they operate as "knowledge regimes" (Adger et al., 2001), the making of which implies power struggles so that one discursive configuration can gain dominance over the other. Understanding how media discourses prioritize certain perspectives and understate others is indeed critical as media coverage has the potential to amplify or attenuate risk issues and therefore influence public perception (Kasperson et al., 1988; Church et al., 2017, Flint et al., 2019).

In this perspective, understanding the construction of a dominant discourse makes it possible to elucidate the political choices associated with it, in our case the range of solutions available to mitigate or adapt to environmental risks, implemented through particular public policies and institutional arrangements (Hajer and Versteeg, 2005; Rinne and Nygren, 2016). Previous research on drought discourses has focused on the importance of documenting the framing of drought as it influences public perceptions, decision-making, and practices. Our research proposes to reverse the approach and i) to focus on how media discourses frame solutions to environmental issues and ii) to unveil the "complex webs of interests, ideologies, and power" 
(Molle, 2008: 132) at the origins of the emergence of such solutions. Following a political ecology approach, in that it focuses on discourses as revealing asymmetrical power relations (Adger et al., 2001; Svarstad and Benjaminsen, 2017; Parks, 2018) and tackles the questioning of scientific arguments mobilized in the implementation of environmental public policies (Forsyth, 1996; 2003; Kull, 2004), we propose to look at the solution that is now favored worldwide as the main tool for drought mitigation: water conservation, i.e. the reduction in water loss and water use through mainly demand-management (March et al., 2013; Maggioni, 2014; Vickers, 2017). Water conservation has been indeed gaining momentum over water supply management strategies, such as reservoirs building, inter-basins transfers, new technologies (i.e., desalination) or nonconventional water resources (e.g., greywater and rainwater uses). How to explain the success story of water conservation, from a notion coined by experts belonging to the technical and academic world to a notion that can now be found on every street corner, especially in American desert cities (Figure 1)? How did this notion become an imperative rarely challenged, even though it relies on the efforts of individuals, who are made responsible for the imbalance between water supply and demand?

Our objective is to retrace the construction of the water conservation narrative, defined as a "social construction about a specific case [i.e., drought mitigation]" (Benjaminsen and Svarstad, 2008, p.51) to understand how it has become a dominant strategy since the early 2000s. Water conservation corresponds to a shift from highly centralized water management dominated by experts (Gleick, 2002) to the integration of multiple stakeholders, and in particular of water users asked to reduce their water uses (Brooks, 2007; Brooks and Holtz, 2009). Thus, the implementation of water conservation aims largely at changing people's behavior regarding water consumption and relies strongly on public outreach and participatory awareness campaigns (Wutich et al., 2014; Liang et al., 2018; Boyer et al., 2020). For example, water providers can directly mobilize the local newspapers in which advertisements are published encouraging users to monitor their consumption (Howarth and Butler, 2004). In this regard, it has been shown that inhabitants well informed through news media tend to enact conservation behaviors (Dolnicar et al., 2012; Quesnel and Ajami, 2017; Moglia et al., 2018). In this paper, we focus instead on what is said about water conservation, and by whom, in the press, as it is a dimension of the public sphere (Habermas, 1974; 1989), a deliberative space that potentially engages opposing viewpoints that affect civic and community life. We seek to pay closer attention to what different actors want to see happen, in pursuit of which goals and by which means (Rinne and Nygren, 2016).

We analyzed the water conservation discourse in local daily newspapers published in Phoenix and Tucson (Arizona, USA). Both cities constitute key study sites for examining the profound consequences of climate change on water resources in arid lands (Bolin et al., 2010; Zuniga-Teran and Staddon, 2019). As they are tackling global changes effects on already overallocated water resources, Phoenix and Tucson can be considered as laboratories where technical and political responses are first elaborated that may be of interest to other cities facing similar problems (Megdal and Forrest, 2015; Hondula et al., 2019). In those two desert cities, drought has become the dominant environmental explanation (Forsyth, 2003) to water scarcity issues and water 
124

125

conservation has become a "nirvana concept" - a concept quickly integrated into public policies that represent a source of satisfaction for most of the stakeholders (Molle, 2008) - as it lies at the core of Arizona's strategy to reassure that threats associated to drought will be successfully managed to sustain growth in this booming region of the U.S. (Hirt et al., 2008; 2017). Based on a corpus of 520 articles published between 1999 and 2018 in the Arizona Republic (Phoenix) and the Arizona Daily Star (Tucson), this research proposes a quantitative textual analysis of the water conservation narrative.

To understand how water conservation was constructed in the press as a consensual imperative for coping with water scarcity, we address three main questions: i) how much attention does water conservation get in the press when it comes to water and drought issues? ii) who are the actors involved when it comes to promote water conservation through newspapers and what are their relationships (conflictual vs. cooperative)? iii) as water conservation remains a difficult concept to define (Baumann et al., 1984; Butler and Memon, 2005; Brooks, 2006), which interpretation does the press contribute to making as dominant?

\section{Materials and methods}

\subsection{Water conservation in Arizona desert cities}

Global changes have already profound consequences for the climate of the American Southwest and its over-allocated water supplies. As a result, the region is a key site for exploring ways to manage worsening droughts and pressures on water resources, especially in urbanized arid lands (Bolin et al., 2010; Hondula et al., 2019).

Phoenix and Tucson in Arizona are amongst the fastest growing cities in the United States (Benites-Gambirazio, 2016; US Census, 2019). Located in the arid Sonoran Desert, their growth is closely tight to the availability of water supplied by local aquifers and large infrastructures (dams, aqueducts, canals) built during the 20th century in the Colorado River Basin (Kupel, 2003) following a Promethean and extractivist approach to natural resource development (Worster, 1985; Sheridan, 2012) (Figure 2). In Arizona, the water conservation imperative was first formalized in 1980 through the Groundwater Management Act (GMA), considered at the time as a leading innovation. The law, by defining objectives for the sustainable management of groundwater - then Arizona's main water supply - changed the state's relationship to water resources (Connall, 1982; Jacobs and Holway, 2004; Poupeau et al., 2016). Groundwater is since then considered a nonrenewable resource to be protected. The Colorado River water transported by the Central Arizona Project (CAP) has however become central as it is classified as a renewable water resource (Bernat et al., 2020). The GMA created a new state water agency, the Arizona Department of Water Resources (ADWR), which supervises five Active Management Areas (AMAs) in which all uses of groundwater are quantified and regulated. This law places water demand management at the 
core of its objectives and defines an ambitious water conservation program to be carried out by the various users of the resource in Arizona, to limit and eventually eliminate pumping from the aquifers (Colby and Jacobs, 2007).

The conservation goals are set at the scale of the AMA where decennial management plans provide requirements and guidelines. We will focus here on municipal water uses in Phoenix and Tucson AMAs. As early as 1984, the first management plan required a "reasonable reduction in per capita use" with a threshold of 140 gallons per person per day. It presented the following guidelines for undertaking demand management (Phoenix AMA, 1984; Tucson AMA, 1984): restriction of water deliveries to "turf-related facilities" (e.g., sports fields; golf courses); the prohibition of groundwater delivery for large private swimming pools and large private recreational ponds or lakes; the need to reduce leaks and water loss in local distribution systems; the need to implement efficient irrigation practices (e.g., drip irrigation, irrigation controllers); need to promote the planting of low water use vegetation; need to support low water use plumbing devices development (Phoenix AMA, 1984; Tucson AMA, 1984). The most recent documents (Phoenix AMA, 2016; Tucson AMA, 2016) organize water conservation around three main axes: i) reducing per capita water consumption; ii) encouraging the use of best available water conservation practices; iii) maximizing the efficient use of all water supplies. Finally, the documents highlight that public information and education programs are essential to the success of urban water conservation programs. As the ADWR and most municipal water utilities like to point out, Arizona's major cities have seen their populations grow steadily while the amount of water use per capita has declined. For example, from 267 gallons per capita per day (GPCD) in Phoenix and 168 gallons GPCD in Tucson in 1984, these figures have decreased to 202 and 130 gallons respectively in 2015 (Tucson AMA, 1984; 2016; Phoenix AMA, 1984; 2016). This gradual decrease in municipal water consumption can be explained by municipal landscaping (i.e., xeriscaping programs) and plumbing ordinances (e.g., install reduced-flow plumbing fixtures) adopted in the 1980s and 1990s and extensive information and education campaigns regarding drought and conservation in the 1990s and 2000s (Larson et al., 2009; Hirt et al., 2017).

\subsection{A corpus of articles from the regional daily press}

We examine discourse patterns regarding water conservation through analyses of articles published in Arizona's two major newspapers, namely the Arizona Republic and the Arizona Daily Star. The Arizona Republic, based in Phoenix, is owned by Gannett Company and is the state's main newspaper. From a daily circulation of 574,798 in the early 2000s (Sonnett et al., 2006), the Arizona Republic is today down to an average of 130,000 daily copies in a region - Central Arizona - with a total population of over 4 million. However, it is important to note here that its digital version is regularly consulted by many subscribers. General readers can consult for free up to five articles a month. Since its inception in 1890, the newspaper has consistently supported Republican candidates until the 2016 presidential election, when it ran in favor of Hillary Clinton. Based in Tucson, the Arizona Daily Star, now with an average daily circulation of 106,436, covers the Southern Arizona region with a population of 1,3 million. The newspaper was founded in 1877 by 
L.C. Hughes, an elected Democrat who became the 11th governor of the Arizona Territory in the late 19th century. The editorial line of the newspaper has always been closer to the Democratic party. Both newspapers have environmental journalists covering local and regional issues, and reporting on events triggered by weather conditions (e.g., drought, extreme heat, heavy rain, and flash floods). The analysis of the local press makes it possible to assess what is considered newsworthy (Dispensa and Brulle, 2003): what kind of events (natural hazards or management decisions) are likely to interest readers.

The political divergences mentioned above does not significantly impact environmental coverage as both newspapers contribute to re-affirm perceptions about the necessity of growth for political and economic reasons (Christopher, 2008; Poupeau et al., 2016). However, Phoenix and Tucson face two different hydro-geographic situations: located at the confluence of several local watersheds, Phoenix has access to a more diversified water resource through the Salt and Verde River hydraulic system; Tucson's supply, in the Santa Cruz watershed, relies on water from the Central Arizona Project for more than $80 \%$ and is directly threatened by shortages on the Colorado River (Megdal and Forrest, 2015). How newspapers reflect on drought and water issues depends less on their political inclinations than on the importance of regional particularities in terms of water resources.

Our study period begins in January of 1999 and ends in December 2018. January 1999 corresponds to the eve of the intense drought which has shaped the last 20 years in the Southwest and before public awareness of drought began to grow, especially from 2002 onwards (Sonnett et al., 2006). We consulted online databases ProQuest and Access World News. To focus on how the emergence of severe drought has affected perceptions of water and decisions on water issues in Arizona, we identified news article through keyword searches and selected all articles containing the term "water" (main subject) along with "drought" (all text). These keywords allowed us to collect a sufficiently large number of articles that show a diversity of objects, situations, and problems reported in the press. We had previously tried more targeted queries (e.g., "water +conservation") which left out too many articles. A total of $N=520$ articles published between January 1999 and December 2018 were identified. This corpus has a total of 622,126 words. The distribution of articles through time is uneven (Figure 3), with peaks corresponding to periods of severe drought. The first peak corresponds to the period of a severe to extreme drought affecting more than 80\% of Arizona between 2002 and 2005; after a year of relief in 2006, 70\% of Arizona is then under a severe drought alert until 2008 (according to the U.S. Drought Monitor ${ }^{1}$ ); the second peak (2014-2018) corresponds to the prolonged drought effects on Lake Mead, the principal reservoir supplying the region (Figure 2), reaching a low level and threatening water users with a shortage. The year 2018 is marked by the Drought Contingency Plan (DCP) negotiations, overseen by the US Bureau of Reclamation (USBR) with the goal of establishing a regional and long-term drought strategy.

\subsection{Data analysis}

\footnotetext{
${ }^{1}$ See US Drought Monitor's data for Arizona here: https://www.drought.gov/states/arizona
} 
245

First acquired in pdf format, we formatted the 520 articles for analysis with two openaccess software allowing quantitative textual analyses (Lebart et al., 1998; 2019): IRaMuTeQ (Ratinaud, 2009; Chaves et al., 2017) and TXM (Heiden, 2010). They both work in relation to the R software (R Core Team, 2018) which enables different processing and statistical analysis of texts. IRaMuTeQ and TXM both provide pre-processing tools such as lemmatization (i.e., grouping inflected forms together as a single base form) or the calculation of word frequency in the corpus. In contrast with content analysis or with a qualitative study of texts, the quantitative textual analysis allows the interpretation phase to be performed after the procedure, following an explanatory sequential mixed method. IRaMuTeQ and TXM both allow users, with just one click, to return to the text in order to observe the actual occurrences in context, and thereafter to construct qualitative interpretations.

IRaMuTeQ divides the corpus into text segments (i.e., segments of homogeneous size while respecting as much as possible the structure of the language, clauses or whole sentences of 40 words on average) and performs a top-down approach for hierarchical clustering as developed by Reinert for his ALCESTE method $(1983$; 1990) to analyze the corpus's lexical structure (Cottet et al., 2015; Comby et al., 2019; Adam et al., 2020). Developed since the 1980s, the classification algorithm has proven robust. It produces a dendrogram displaying a certain number of clusters and specifying the percentage of text segments in each cluster. The clustering tree is inductive and proceeds directly from the data. Each cluster is associated with a list of lemmas ranked according to their Chi-squared values, from the highest scores on top of the list to the lowest (to express the strength of the link between one lemma and the cluster) (Marpsat, 2010). Each cluster can then be run through a similarity analysis. This calculation is based on graph theory and more specifically, on the Fruchterman-Reingold algorithm (1991) using cooccurrences. It aims at studying proximity and relationships between components (the lexical forms) of a set (the considered cluster) using a maximum tree (Ratinaud and Marchand, 2012).

If the top-down clustering reveals the main "lexical worlds" structuring the entire corpus, the similarity analysis shows a given cluster's internal organization.

Both these statistical treatments rely on the co-occurrence analyses of specific lexical forms (Lebart et al., 1998). Through TXM, we conducted a more detailed analysis of all the cooccurrences happening throughout the corpus, for different text sections of different lengths. Moreover, TXM offers tools to apprehend the diachronic dimension of the corpus's textual content and allows full-text search techniques. This allows for retracing the emergence and the evolution of narratives, as they describe changes in public perceptions of water scarcity issues (Molle, 2008; Whitfield et al., 2015; Leong, 2021). In the results part below, we combine these quantitative analyses with a qualitative approach thanks to different quotations. We retrieved most quotations thanks to TXM's "concordances" function that makes it possible to perform a query on a "pivot" word which allows a content analysis of what precedes and follows a term or expression. 


\section{Results}

\subsection{The growing importance of the water conservation narrative}

The agora of the regional daily press is highly sensitive to local concerns and provides insight into issues over time (Spencer and Triche, 1994; Comby et al., 2014; 2019). Thus, with the newspaper corpus, we can examine the process through which narratives are constructed to understand why environmental policies end up assuming a particular shape (Roe, 1994; Lockwood, 2011). In the corpus, the lemmas "conservation" ( $n=709)$, "conserve" $(n=223)$ and "save" (n=278) appear 1,210 times. Figure 4 shows how the use of the lemmas "conservation" and "save" evolves between 1999 and 2018 throughout the corpus. We observe a particularly strong progression of the term "conservation" between 1999 and 2007: from a single occurrence of the word "conservation" in 1999, we count 112 in 2005 - the peak year for the word "conservation" in the corpus - and then 60 times in 2007. The progressive entry into a period of drought from 2002 onwards lies in the background of this increase. In March 2003, Arizona Governor Janet Napolitano (Democrat; 2003-2009) launched the Arizona Governor's Drought Task Force, bringing together water managers and members of the local legislature. In 2004, their work led to the publication of the Arizona Drought Preparedness Plan, which created the Drought Interagency Coordinating Group providing the Governor with twice-yearly reports on the status of drought and water resources. Starting in 2004, the drought and the Arizona Governor's actions brought to the forefront the water conservation measures recommended by the Groundwater Management Act and the Active Management Areas management plans, which had been relatively ignored until then.

The top-down method for hierarchical classification shows how two main poles structure the clustering tree: i) the first emphasizes water management (Clusters $1 ; 2 ; 3 ; 6$ ); ii) the second is organized around biophysical issues associated with the availability of water resources (Clusters 4 and 5) (Figure 5).

Within these two overarching poles, clusters are assembled into subgroups.

Among the clusters centered on management issues, clusters 3 ("mead"; "cap"; "colorado") and 2 ("interior"; "secretary"; "state") form a subgroup as they are both tackling water management at the level of the state of Arizona and of the entire Colorado River Basin through large-scale hydraulics. Each corresponds to a different facet of water management. Cluster 3 corresponds to the empirical and technical dimensions of water management in the Colorado basin to avoid a shortage: "foot"; "acre"; "shortage". Cluster 2 refers to the political aspect ("agreement"; "deal"; "negotiation") of water management.

Clusters 6 and 1 are related to the implementation of water policies at the local level as it involves local actors (cluster 6: "public", "director", "group") and affects local development orientations (cluster 1: "groundwater", "pump", “well”, “county"). They also articulate two 
different aspects of water governance. Indeed, cluster 6 focuses on the governance aspect of water management at the local level (public policies, relations, and cooperation with other actors such as universities, institutes or associations). Cluster 1 focuses on the operational side, especially through land-use planning, and the challenge of water resource scarcity in the context of rapid urban growth. It shows a tension between residential and municipal uses ("city"; "home") and agricultural uses ("farm"; "crop"; "rural").

Finally, the clusters that address biophysical issues are divided into two sub-themes. Cluster 5 relates to the observation and measurement of climatic and meteorological events ("winter"; "snow"; "runoff") that condition the availability of the water resource. Cluster 4 is more concerned with the water needs of ecosystems ("fish"; "canyon"; "tree").

This top-down classification highlights an opposition between two visions of water management: $66.1 \%$ of the text segments see it as a techno-managerial issue, handled by large technocratic institutions; $33.9 \%$ see it much more from the perspective of environmental protection and of scientific attention to climate change. We note that the word "conservation" does not belong to the environmental lexical world in the corpus but rather strongly contributes to characterize cluster 6 . This lexical cluster focuses on water conservation as a management tool. It contains the main elements of the demand management toolbox: a set of public policies ("public"; "policy") that gives rise to information dissemination and environmental education campaigns ("campaign"; "education") and that aims to transform individual practices ("person") in order to implement environmentally acceptable options for water management. $18.9 \%$ of the corpus's text segments deal directly with water conservation as a new strategy for water management. According to this graph, with $18.9 \%$ of the text segments, it is the second most important theme structuring the corpus (after climate considerations in cluster 5).

\subsection{Collective efforts towards innovative solutions?}

\subsubsection{A diversity of stakeholders}

According to the results presented above, the inclusion of new actors in water management contributes strongly to the characterization of water conservation practices. Figure 6 therefore shows the actors who appeared more than 100 times in the local newspapers' articles dealing with water and drought. There is a strong domination of governmental actors, at the federal, state, county and city levels. The world of science is also important, through the mention of universities, scientists, researchers and especially hydrologists. Two major types of largescale water consumers are well represented: farmers and developers. We also note the importance of inhabitants and their individual water consumption through the occurrences of "resident", "homeowner" and "family".

To analyze more precisely the set of actors involved in water conservation, and especially the roles they can play, Figure 7 shows the graph of the similarity analysis based on cluster 6 . This tree clearly shows the four major actors of conservation: the ADWR which provides the 
general framework ("resources"-“department”); the municipal level which represents the scale at which public water conservation policies are implemented ("city"); different types of groups which are concerned by the measures ("group") and finally the individual scale ("person").

We see that the theme of water conservation is linked to strong words like "force", "act", "effort". It requires the implementation of creative solutions as shown by the frequent cooccurrences of "conservation" with "create" and "idea". The figure also highlights the issue of financing water conservation programs: "money", "fund".

The network of words around "resource" indicates on the one hand the existence of a "problem" and a "crisis" whose stakes would be "growth" and "development", but also mentions the need to put in place "solutions". This part of the graph highlights a collaboration between public actors and universities.

The network that takes shape around the word "city" translates to the existence of an "issue" that is open to discussion in the deliberative instances mentioned: "council"; "board". The lexical fields of the question and the proposition dominate, as both can be submitted to the civic debate.

The co-occurrences of the word "group" show two kinds of groups involved in water conservation: on the one hand, those concerned with environmental issues, associated with the presence of strong verbs such as "fight", "protect", "support"; and, on the other hand, groups with business-related interests.

Finally, the branches formed around the co-occurrence of "conservation" and "person," indicates not only the importance of the individual scale but above all the extent to which the issue is that of a change in mentalities: "change"; "know"; "think"; "live." It is interesting to note that the word "future" stands out, setting a vision of a horizon that individuals and communities should strive to reach.

\subsubsection{From conflictual to cooperative relations?}

The qualitative analysis shows that the corpus includes the mentions of more than 15 environmental organizations. Among the most frequently mentioned, we find the Sierra Club, followed by the Center for Biological Diversity and The Nature Conservancy. The relationship between associations and other stakeholders is expressed in two ways. The first, conflictual, has ancient roots and aims to denounce the environmental impacts of large hydraulic infrastructures. For example, in 2002, for the 100th anniversary of the U.S. Bureau of Reclamation in charge of developing the arid west since the beginning of the $20^{\text {th }}$ century, a journalist writes in the Arizona Republic (06/17/2002): "not everyone will be celebrating the agency's work tonight. Activists from more than 80 environmental groups have planned a counter-event to protest what they believe is a legacy of ecological neglect at best and wholesale destruction at worst."

The other dimension however is that of cooperation, as this extract from an article presenting the USBR's Colorado River Basin Water Supply and Demand Study in 2012 illustrates: "The report includes four scenarios for dealing with the shortage. One, offered by the 
states and water users, relies on large-scale projects such as pipelines to complement conservation and reuse in filling the gap. Another, presented by environmental groups, favors conservation, storing water in an aquifer above Lake Powell and relatively low-energy desalination of brackish groundwater. The other two scenarios either combine those proposals or use their points of overlap" (12/13/2012, AZ Republic). This last extract shows the participatory and integrated management dimension of water conservation. Compared to the excerpts from the early 2000s, there has been an evolution of water management from a highly conflictive field to the inclusion of and collaboration with environmentalist groups in decision-making.

\subsection{Promoting a water conservation lifestyle}

This final part of the analysis looks at the framing of water conservation across the entire press corpus. Table 1 shows the most frequent co-occurrences of the word "conservation". This table describes water conservation primarily as an incentive strategy ("promote "; "encourage"; "push") that involves communication ("message"; "campaign") and education efforts. Furthermore, we see in Table 1 that the terms "ethic", "culture" and "lifestyle" are frequent cooccurrents of conservation. The government of J. Napolitano originated this rhetoric of water conservation as a new "lifestyle" that still prevails today: "we need to develop that culture of conservation (that Gov. Janet Napolitano has urged)" says an Arizona Republic's article on 08/28/2005 (see also the weight of "napolitano" in Figure 5, cluster 6). The ambition, and even the challenge, of water conservation lies in changing the habits and practices of the inhabitants towards water. Indeed, for decision-makers, it seems very important not to alert, nor to frighten. Their goal is rather to propose a new model and convince individual water users that conservation is preferable: "saving water is also a lifestyle change for many people. It requires many to consciously change their habits. It takes a strong leader to coax those changes from voters who like wide, green lawns or long, hot showers" (AZ Republic, 07/01/2005). As shown by this excerpt, there is a dimension of social acceptance, and more broadly a political stake tied to the proposal of water conservation.

Table 1 also shows that the word "specialist" appears in third position in the list of water conservation's co-occurrents. Indeed, the carriers of this message are the water conservation specialists who work for the water utilities at the municipal level. Their main task is to implement demand-management measures on the technical (leak management, water use data processing) and social sides (information, education) (Hamilton, 2013). Our press corpus presents 40 interviews conducted with water conservation specialists.

Surprisingly, Table 1 presents both the words "voluntary" and "effort" but also the words "mandatory" and "imposes" which are completely opposite. A query around the term "mandatory" in the TXM concordances function shows that if the word is totally absent from the corpus in 1999, 2000 and 2001, it appears 9 times in 2002, 11 times in 2003, then 17 times in 2004 to drop to 5 times in 2005. Between 2008 and 2015, in a period of respite from drought conditions, the word is no longer mentioned. We can see that the word "mandatory" refers 41 times to the fact that water conservation measures are not mandatory. For example, in August 2002, a water district 
office manager in North Phoenix tells the Arizona Republic: "All we can do is beg and plead for people to stop watering lawns. District bylaws don't allow mandatory restrictions" (08/23/2002).

Actually, the word "mandatory" refers only 24 times to the fact that water conservation measures are mandatory, including in California, in Southern Nevada, in Colorado, in Flagstaff in Northern Arizona, and once in Oro Valley, a suburb of Tucson in 2007. Indeed, throughout the corpus, "mandatory" measures are seen as very negative and limiting. In the following excerpt, mandatory water conservation measures lie among the "disasters" - between water shortages and ravaged farms - that could affect Arizona residents as an effect of the drought: "Climate experts say even a reasonably normal winter could ease the drought's effects, but a dry one, on top of all the other dry ones, would trigger new disasters: water shortages, mandatory conservation, ruined farms and ranches, despoiled forests and wildfires" (01/19/2003, AZ Republic).

\section{Discussion}

\subsection{Water conservation: for the seek of the common good}

The analysis of media discourse has proven quite efficient in reconstructing discursive trajectories and political strategies associated with them (Burke et al., 2015; Duffy, 2016; Comby et al., 2019). Indeed, news media coverage of natural risks often follows regulatory events and political actions (Hurlimann and Dornicar, 2012; Wei et al., 2015). Since the early 2000s and the political reaction of Gov. Janet Napolitano to the 2002 drought, water conservation has gradually become the watchword for water decision-makers in Arizona as they are confronted with rapidly declining reservoirs and uncertainty about long-term water supplies. The media's interest for politics and policies can be interpreted as following two different logics. First, it works within an Habermasian realm which considers the press as supposed to "support reflection and value on policy choice" (Baker, 2002: 148) and to support the search for a general agreement on common good (Benson, 2009). Second, as discourses embody power in the way they help make people more compliant and governable (Foucault, 1980), we can push the interpretation further and conclude that the importance of political decisions in the newspapers can be explained by their reliance on government information sources but also by the need to govern the population, and thus to convince it of the validity and legitimacy of the decisions taken. The press becomes an instrument of public policies and their social acceptance.

Consistent with the results of studies conducted by Sonnett et al., (2006) or Addo et al., (2019), most of the sources quoted in our daily press corpus are official sources, especially from government at different levels (federal, state, county, city) and from universities. They correspond to "meaning-making institutions" (Browne and Keil, 2000) that contribute to set narratives with the ability to be realized, not because of the "correctness of [their] assumptions" but because of the power position of those communicating (Whitfield et al., 2015: 134). These protagonists have enough legitimacy and credibility to present themselves as the protectors of a sustainable and 
responsible development and, most importantly, to define what is common good and to closely associate water conservation with it. Finally, in doing so, they are also able to construct as ignorance the failure to behave accordingly to their definitions (Cher, 2019).

The importance of the vocabulary of the "lifestyle" or of the "cultural change" that is required with water conservation shows that the challenge is to modify city dwellers' habits. Acculturated by this new narrative of Arizona's desert cities as champions of water conservation, residents are more likely to be gradually convinced that they must change their habits. The objective is to shape a reasonable water user, following the principle of the eco-citizen. The success of the water conservation lifestyle is therefore largely based on the individual scale and the involvement of individuals who must be convinced, without being frightened. Implementing the water conservation lifestyle allows to achieve two objectives: i) postpone or avoid the risk dimensions (i.e., water shortage) associated with the drought; ii) continue to sell the quality of life that makes the region attractive, promoted as a lifestyle destination since the 1920s (Hirt et al., 2008; Schipper, 2008; Sheridan, 2012). However, this strategy helps individualizing responsibility for the current ecological crisis. The guilt-inducing small gestures imperative makes it indeed possible to avoid questioning the viability of limitless capitalist urbanization in the desert (Davis, 2002; Boyer et al., 2020; O'Neill and Boyer, 2020).

\subsection{A process of depolitization}

With water conservation, it seems that the logic of adaptation takes precedence over that of mitigation of global environmental changes. In a sense, the actors seem to have given up discussing the chosen development models (e.g, mega oasis cities in the desert) that strongly contribute to the imbalance between water resource availability and demand. Given the emphasis in the press corpus on biophysical issues (Clusters 4 and 5) that condition the availability of the water resource, the problem of water scarcity is presented as a natural phenomenon in Arizona. First, this natural fact is the one of aridity which characterizes the region, the Sonoran Desert. Second, the "natural" phenomenon which explains the difficulties faced by water managers in the 21 st century is more and more - since the 2010s - presented as climate change. Thus, our results highlight clearly how water scarcity is explained primarily by natural causes. Such an observation is in line with the work of K. Bakker (1999; 2000) in the United Kingdom and especially M. Kaika (2003) in Greece, which has shown that drought has served as "the 'ferment' for (...) political-economic transformations" (p.919) towards a more neoliberal direction (Edwards, 2013).

This discourse, which places great emphasis on "natural" factors and climate change, borrows from the typical "blame it on nature" rhetoric identified by E. Swyngedouw (2011) in other case studies with similar large water infrastructures projects (e.g, Spain; Ecuador). This rhetoric aims to legitimize and make socially acceptable the political and economic orientations chosen for water management, which very often take the form of hydrosocial fixes (Swyngedouw, 2013). According to E. Swyngedouw, a hydrosocial fix is achieved through the displacement of water resource management from an arena that has become conflictual (i.e., water supply management) to the 
point of slowing down the processes of accumulation, production and consumption to new political spaces (i.e., the ones framing demand management) for water resources management issues. It is therefore a question of adapting the system each time and reproducing "a development trajectory" (Swyngedouw, 2013: 262). Demand management allows indeed for a scalar fix (Smith, 1984; Brenner, 1998; Harvey, 2001; Cohen and Bakker, 2014) since the solution envisaged consists of changing scales, from national and regional scales to a local (municipality) or even micro-local scale (home; individual). Molded with environmental concerns on the preservation of resources, water conservation also operates as a socio-ecological fix (Eckers and Prudham, 2017). It intends changes in the modes of regulation at the origin of new landscapes (especially xeriscapes through the water conservation lifestyle) (Figure 8), in the ways water circulates in the city (e.g, through upgraded water fixtures) and new social configurations: the turn towards more cooperation and collaboration in a post-conflict context (Fleck, 2016). Other findings have therefore shown that more than a political choice, water conservation is framed as a necessity to ensure the survival and flourishing of desert cities (Poupeau et al., 2018). Therefore, the idea is to make it a consensual practice articulated around a win-win principle between environmentalists, water managers, and developers. From a political ecology perspective, such a depoliticization of water issues is questionable but can also be explained by a pragmatic strategy in the context of the increasingly polarized political spectrum, a trend observed worldwide. In Arizona, as the region is still culturally and politically attached to individual freedoms (Altheide et Johnson, 2011; Ross, 2011), the social acceptance of water conservation must perhaps go first through this depoliticization process of the ecological challenged of desert cities.

\subsection{Building consensus: from environmentalist fights to "unholy alliances"}

The quantitative textual analysis we conducted shows that water conservation belongs mainly to the lexical world of administrative and technical water management. This result highlights how the press is defining water conservation within an administrative rationalist framework. According to Dryzek (1997), the environmental discourse of "administrative rationalism" offers to solve problems through bureaucracies of experts and managers. He notes that administrative rationalism has close similarities with the conservationist discourse that emerged in the U.S. in the late $19^{\text {th }}$ century and argued for the careful, rational management of natural resources (Hays, 1959; Brulle, 1996). Following this model, the administrative state is in charge of issuing water conservation mandates (e.g., the Groundwater Management Act of 1980; the successive AMA management plans), water managers are implementing specific water conservation measures (e.g., the water conservation specialists at the municipal levels), and scientists and advocacy groups' role is to communicate the rationale on why water conservation is so important. This model is therefore far from new and is implemented according to a top-down logic, strongly supervised by the institutions. Thus, water conservation does not challenge power structures in place. In the contrary, while environmental organizations have opposed large infrastructures and their management by centralized and bureaucratic agencies, the press corpus shows that water conservation functions as 
a compromise and allows a new cooperation movement between water managers and environmental organizations. The strategy of water managers in Arizona has proven to be successful worldwide, and some of the discursive tools developed are being mobilized in other English-speaking drylands (e.g., in Australia, in South Africa) (Boyer et al., 2020).

In our analysis, the text segments dealing specifically with water conservation are characterized by the diversity of the actors mentioned. This diversity reflects that the implementation of demand management follows a governance-based model (Brooks, 2006) defined as a neutral, optimistic, managerial vision of collective action. Following Adger et al. (2001), the administrative rationalist discourse seems also to join the typical "managerial discourse" on the environment in that water conservation is depicted as a win-win solution for, on the one hand, actors fighting for the health of ecosystems and, on the other hand, proponents of economic growth. However, water managers and political decision-makers do not seem to incorporate views of the environment that consider water as more than a material commodity vital for economic growth. Water conservation is even accepted only insofar as it is not hostile to Arizona's growth (Sheridan, 2012; O’Neill et al., 2018). This political alliance between water managers, political decision-makers and environmentalists can therefore be seen as "unholy" or "strange" (Swyngedouw et al., 2002). For example, it is interesting to note that in the corpus, we do not really find trace of any alternative propositions (e.g., controlling growth, massive turn towards rainwater harvesting or greywater reuse, etc.): the press most often echoes the popular detestation of restrictive water conservation measures (Hughes, 2012; Inskeep and Attari, 2014); the regulation of land use and the limitation of urban sprawl, requested by many since the 1970s (Logan, 1995; Gober et al., 2013) is not mentioned. Indeed, similar findings (Swyngedouw et al., 2002) analyze this form of activism involved with dominant institutions as working only towards social acceptability of top-down policies which contributes to closing down the emergence of alternatives.

\subsection{Epilogue: in Arizona, despite water conservation, the water shortage has come}

Due to drought conditions that have lasted since the early 2000s, in Spring 2021, the level of Lake Mead has reached $1070 \mathrm{ft}$., its lowest level in history. On August 16, 2021, the Federal Bureau of Reclamation has announced the first ever water shortage on the Colorado River, which is $36 \%$ of Arizona's state water supply (USBR, 2021). Their hydrological model even predicts that the reservoir level will drop below $1050 \mathrm{ft}$. by April 2023. By 2022, Arizona is expected to lose $20 \%$ of its water supply. More recently, Arizona newspapers have been mentioning solutions reactivating the paradigm of water supply management, such as an inter-basin transfer from the Mississippi River. Such projects are indeed more newsworthy than the progressive effort to change people's habits. Our study could be completed to test the following hypothesis: in the event of a crisis, the paradigm of water conservation - composed of a multitude of expedients whose definition remains vague - is slowly put away as climate change and emergency justify the return to large infrastructure projects (Crow-Miller et al., 2017). Indeed, in various regions of the world, 
recent analyses have shown the role of the climate discourse in the reframing of mega-projects (Ahlers et al., 2015 in Eastern Himalaya; Warner et al., 2017 in Ecuador; O'Neill, 2020 in California; Flaminio, 2021 in Australia).

Our results show that in the past 30 years water conservation has gained attention in the media, as a drought management and water governance tool. Through the press, among other media - social media are also particularly mobilized in the framing of water conservation (Boyer et al., 2020) water conservation is defined as a successful and optimistic solution to fix the water scarcity issue, exacerbated by the recurrence of droughts. Indeed, it functions as a consensual solution supported by government actors that brings together different types of stakeholders who can work together to sustain urban water security in a drier world. This consensus is made possible by the integration of environmental issues into water conservation which is now widely considered as a "good" way to address ecological issues in water management (Gleick, 2002; Savenjie and Van Der Zaag, 2002; Moglia et al., 2018). As a result, this consensual version of water politics avoids rethinking and reconsidering the power structures organizing water management, especially since this would imply questioning a complex set of actors, devices, investments, and infrastructures that are characterized by a certain inertia and path dependency. It proposes a weak sustainability model that emphasizes the least economically and socially costly solutions: in particular, water conservation focuses mainly on moderating water users demand and thus participates in the individualization of responsibility in mitigating global environmental change impacts on society. Thus, our study shows that the dominant discourse of water conservation does not propose a shift in development paths in a manner that would foster greater resilience against climate change. These results on water issues could also certainly apply to other topics related to global environmental change, such as energy alternatives to reduce greenhouse gas emissions or changes in agricultural practices to preserve biodiversity.

\section{References}

Adam, M., Cottet, M., Morardet, S., Vaudor, L., Coussout, L. and Rivière-Honegger, A., 2020. Cycling along a River: New access, new values?. Sustainability, 12(22), p.9311. DOI: https://doi.org/10.3390/su12229311

Addo, I.B., Thoms, M.C., Parsons, M., 2019. The influence of water-conservation messages on reducing household water use. Applied Water Science, 9(5), pp.1-13. DOI: $\underline{\text { https://doi.org/10.1007/s13201-019-1002-0 }}$

Adger, W.N., Benjaminsen, T.A., Brown, K. and Svarstad, H., 2001. Advancing a political ecology of global environmental discourses. Development and Change, 32(4), pp.681-715. DOI: https://doi.org/10.1111/1467-7660.00222 
650 Altheide, D.L. and Johnson, J.M., 2011. Living in Arizona: Reflections on Life in the Tumultuous Sunbelt.

651 Cultural Studies $\leftrightarrow$ Critical Methodologies, 11(4), pp.346-358. DOI:

652 https://doi.org/10.1177/1532708611414660

Baker, C. E., 2002. Media, markets, and democracy. Cambridge University Press, Cambridge.

Bakker, K., 1999. Deconstructing discourses of drought. Transactions of the Institute of British Geographers, 24(3), pp.367-372. DOI:

https://doi.org/10.1111/j.0020-2754.1999.t01-1-00367.x

Bakker, K., 2000. Privatizing water, producing scarcity: The Yorkshire drought of 1995. Economic Geography, 76(1), pp.4-27. DOI: https://doi.org/10.1111/j.1944-8287.2000.tb00131.x

Baumann, D.D., Boland, J.J. and Sims, J.H., 1984. Water conservation: The struggle over definition. Water Resources Research, 20(4), pp.428-434. DOI: https://doi.org/10.1029/WR020i004p00428

Bell, S., 2009. The driest continent and the greediest water company: newspaper reporting of drought in Sydney and London. International Journal of Environmental Studies, 66(5), pp.581-589. DOI: https://doi.org/10.1080/00207230903239220

Benites-Gambirazio, E., 2016. The social logic of urban sprawl: Arizona cities under environmental pressure. Bankruptcy in the Land of Plenty, CRC Press, pp.121-140.

Benjaminsen, T.A. and Svarstad, H., 2008. Understanding traditionalist opposition to modernization: Narrative production in a Norwegian mountain conflict. Geografiska Annaler: Series B, Human Geography, 90(1), pp.49-62. DOI: https://doi.org/10.1111/j.1468-0467.2008.00275.x

Benson, R., 2009. Shaping the public sphere: Habermas and beyond. The American Sociologist, 40(3), pp.175197. DOI: $10.1007 / \mathrm{s} 12108-009-9071-4$

Bernat, R.F., Megdal, S.B. and Eden, S., 2020. Long-Term Storage Credits: Analyzing Market-Based Transactions to Achieve Arizona Water Policy Objectives, Water, 12(2), p.568. DOI: https://doi.org/10.3390/w12020568

Bohensky, E.L. and Leitch, A.M., 2014. Framing the flood: a media analysis of themes of resilience in the 2011 Brisbane flood. Regional Environmental Change, 14(2), pp.475-488. DOI:

https://doi.org/10.1007/s10113-013-0438-2

Boyer, A.L., Vaudor, L., Le Lay, Y.F. and Marty, P., 2020. Building Consensus? The Production of a Water Conservation Discourse Through Twitter: The Water use it Wisely Campaign in Arizona. Environmental

688 Boykoff, M.T. and Boykoff, J.M., 2007. Climate change and journalistic norms: A case-study of US mass689 media coverage. Geoforum, 38(6), pp.1190-1204. DOI: https://doi.org/10.1016/j.geoforum.2007.01.008 
694 Brenner, N., 1998. Between fixity and motion: accumulation, territorial organization and the historical 695 geography of spatial scales. Environment and planning D: Society and space, 16(4), pp.459-481. DOI: 696 https://doi.org/10.1068/d160459

697 Brooks, D.B., 2006. An operational definition of water demand management. International Journal of Water 698 Resources Development, 22(4), pp.521-528. DOI: https://doi.org/10.1080/07900620600779699

Brooks, D. B. and Holtz, S., 2009. Water soft path analysis: from principles to practice. Water International, 700 34(2), pp.158-169. DOI: https://doi.org/10.1080/02508060902839940

701 Browne, D.R. and Keil, R., 2000. Planning ecology: The discourse of environmental policy making in Los 702 Angeles, Organization \& Environment, 13(2), pp.158-205. DOI: https://doi.org/10.1177/1086026600132002

Brulle, R.J., 1996. Environmental discourse and social movement organizations: A historical and rhetorical perspective on the development of US environmental organizations. Sociological Inquiry, 66(1), pp.58-83.

Burke, B.J., Welch-Devine, M. and Gustafson, S., 2015. Nature talk in an Appalachian newspaper: What environmental discourse analysis reveals about efforts to address exurbanization and climate change. Human Organization, pp.185-196

Butler, D. and Memon, F. A., eds., 2006. Water demand management. Iwa Publishing, London.

Changnon Jr, S.A. and Easterling, W.E., 1989. Measuring drought impacts: The Illinois Case. JAWRA Journal of the American Water Resources Association, 25(1), pp.27-42. DOI: https://doi.org/10.1111/j.17521688.1989.tb05663.x

Chaves, M.M., dos Santos, A.P., dos Santosa, N.P. and Larocca, L.M., 2017. Use of the software IRAMUTEQ in qualitative research: an experience report. In Costa, A.P., Reis, L.P., de Sousa, F.N., Moreira, A. and Lamas, D., eds., Computer supported qualitative research, Springer, Studies in Systems, Decisions and Control, 71, pp. 39-48.

Cher, S.D., 2019. Drought, Discourse, and Dominance: How Newspapers Constructed California's Drought Emergency, 2014-2017. Doctoral dissertation, California State Polytechnic University, Pomona.

Christopher, D., 2008. The Media, Groundwater, and Development: Scientific Input in the Arizona Daily Star, 2006. Doctoral dissertation, University of Wisconsin- Madison. URL: http://digital.library.wisc.edu/1793/28892

Church, S.P., Haigh, T., Widhalm, M., de Jalon, S.G., Babin, N., Carlton, J.S., Dunn, M., Fagan, K., Knutson, C.L. and Prokopy, L.S., 2017. Agricultural trade publications and the 2012 Midwestern US drought: A missed opportunity for climate risk communication. Climate Risk Management, 15, pp.45-60. DOI: https://doi.org/10.1016/j.crm.2016.10.006

Cohen, A. and Bakker, K., 2014. The eco-scalar fix: Rescaling environmental governance and the politics of ecological boundaries in Alberta, Canada. Environment and Planning D: Society and Space, 32(1), pp.128146. DOI: https://doi.org/10.1068/d0813

Colby, B.G. and Jacobs, K.L., eds., 2007. Arizona water policy: management innovations in an urbanizing, arid region. Routledge. 
Comby, E., Le Lay, Y.F. and Piégay, H., 2014. How chemical pollution becomes a social problem. Risk communication and assessment through regional newspapers during the management of PCB pollutions of the Rhône River (France). Science of the Total Environment, 482, pp.100-115. DOI: https://doi.org/10.1016/j.scitotenv.2014.02.137

Comby, E., Le Lay, Y.F and Piégay, H., 2019. Power and changing riverscapes: The socioecological fix and newspaper discourse concerning the Rhône River (France) since 1945. Annals of the American Association of Geographers, 109(6), pp.1671-1690. DOI: https://doi.org/10.1080/24694452.2019.1580134

Connall Jr, D.D., 1982. A History of the Arizona Groundwater Management Act. Arizona State Law Journal, p.313.

Cottet, M., Piola, F., Le Lay, Y.F., Rouifed, S. and Riviere-Honegger, A., 2015. How environmental managers perceive and approach the issue of invasive species: the case of Japanese knotweed s. 1.(Rhône River, France)?. Biological invasions, 17(12), pp.3433-3453. DOI: https://doi.org/10.1007/s10530-015-0969-1

Crow-Miller, B., Webber, M. and Molle, F., 2017. The (re) turn to infrastructure for water management?. Water Alternatives, 10(2), pp.195-207.

Davis, M., 2002. Dead Cities and Other Tales. New Press

DeGaetano, A.T., 1999. A temporal comparison of drought impacts and responses in the New York city metropolitan area. Climatic Change, 42(3), pp.539-560. DOI: https://doi.org/10.1023/A:1005413410160

Dispensa, J.M. and Brulle, R.J., 2003. Media's social construction of environmental issues: focus on global warming-a comparative study. International Journal of sociology and social policy, 23(10), pp. 74105. https://doi.org/10.1108/01443330310790327

Dolnicar, S., Hurlimann, A. and Grün, B., 2012. Water conservation behavior in Australia. Journal of environmental management, 105, pp.44-52. DOI: https://doi.org/10.1016/j.jenvman.2012.03.042

Dryzek, J. S. 1997. The politics of the earth: Environmental discourses. Oxford University Press, Oxford.

Duffy, K., 2016. Setting the drought agenda: A comparative study of local and national newspaper coverage of the California drought, 2013-2015. Doctoral dissertation, Michigan State University.

Ekers, M. and Prudham, S., 2017. The metabolism of socioecological fixes: Capital switching, spatial fixes, and the production of nature, Annals of the American Association of Geographers, 107(6), pp.1370-1388. DOI: https://doi.org/10.1080/24694452.2017.1309962

Edwards, G.A., 2013. Shifting constructions of scarcity and the neoliberalization of Australian water governance. Environment and Planning A, 45(8), pp.1873-1890. DOI: https://doi.org/10.1068/a45442

Fairclough, N., 2001. Critical discourse analysis as a method in social scientific research. In Wodack, R. and Meyer, M., eds., Methods of critical discourse analysis, SAGE Publications Ltd, pp.121-138.

Fleck, J., 2016. Water is for fighting over: And other myths about water in the West, Island Press.

Flint, C.G., Wynn, E., Paveglio, T., Boyd, A. and Bullock, C., 2019. Variations in Newspaper Coverage on Water in the US Intermountain West. JAWRA Journal of the American Water Resources Association, 55(5), pp.1306-1322. DOI:

https://doi.org/10.1111/1752-1688.12780 
Forsyth, T., 1996. Science, myth and knowledge: testing Himalayan environmental degradation in Thailand, Geoforum, 27(3), pp.375-392. DOI: https://doi.org/10.1016/S0016-7185(96)00020-6

Forsyth, T., 2003. Critical political ecology: the politics of environmental science, Routledge.

Foucault, M., 1972. The Archeology of Knowledge, Tavistock Publications, London.

Foucault, M. 1980. Power/Knowledge: Selected Interviews \& Other Writings, Pantheon Books, New York.

Fruchterman, T.M. and Reingold, E.M., 1991. Graph drawing by force-directed placement. Software: Practice and experience, 21(11), pp.1129-1164.

Gleick, P.H., 2002. Water management: Soft water paths. Nature, 418(6896), pp.373-373. DOI: https://doi.org/10.1038/418373a

Gober, P., Larson, K.L., Quay, R., Polsky, C., Chang, H. and Shandas, V., 2013. Why land planners and water managers don't talk to one another and why they should!. Society \& Natural Resources, 26(3), pp.356-364. DOI: https://doi.org/10.1080/08941920.2012.713448

Greene, C., 2021. "Drought isn't just water, it is living”: Narratives of drought vulnerability in California's San Joaquin Valley. Geoforum, 121, pp.33-43. DOI: https://doi.org/10.1016/j.geoforum.2021.02.007

Habermas, J., 1974. The public sphere: an encyclopedia article. New German Critique, 3, pp.49-55.

Habermas, J., 1989. The structural transformation of the public sphere. An inquiry into a category of Bourgeois society, MIT Press, Cambridge.

Hajer, M.A., 1995. The politics of environmental discourse: Ecological modernization and the policy process, Oxford University Press.

Hajer, M. and Versteeg, W., 2005. A decade of discourse analysis of environmental politics: Achievements, challenges, perspectives. Journal of environmental policy \& planning, 7(3), pp.175-184. DOI:

https://doi.org/10.1080/15239080500339646

Hamilton, J., 2013. Careers in Water Conservation. U.S. Bureau of Labor Statistics. URL:

https://www.bls.gov/green/water_conservation/water_conservation.pdf

Harvey, D., 2001. Globalization and the'spatial fix'. Geographische Revue, 2, pp. 23-30.

Haughton, G., 1998. Private profits-public drought: the creation of a crisis in water management for West Yorkshire. Transactions of the Institute of British Geographers, 23(4), pp.419-433. DOI: https://doi.org/10.1111/j.0020-2754.1998.00419.x

Hays, S. P., 1959. Conservation and the gospel of efficiency: The progressive conservation movement, 1890 1920, University of Pittsburgh Press.

Heiden, S., 2010. The TXM platform: Building open-source textual analysis software compatible with the TEI encoding scheme. In Ryo Otoguro, K.I., ed., 24th Pacific Asia Conference on Language, Information and Computation, Institute for Digital Enhancement of Cognitive Development, Waseda University, pp.389-398. 
Hirt, P., Gustafson, A. and Larson, K., 2008. The mirage in the Valley of the Sun, Environmental History, 13(3), pp.482-514. DOI: https://doi.org/10.1093/envhis/13.3.482

Hirt, P., Snyder, R., Hester, C. and Larson, K., 2017. Water consumption and sustainability in Arizona: A tale of two desert cities, Journal of the Southwest, 59(1), pp.264-301. DOI: doi:10.1353/jsw.2017.0017.

Howarth, D. and Butler, S., 2004. Communicating water conservation: How can the public be engaged ?. Water Science and Technology: Water Supply, 4(3), pp. 33-44. DOI: https://doi.org/10.2166/ws.2004.0041

Huang, J., Li, Y., Fu, C., Chen, F., Fu, Q., Dai, A., Shinoda, M., Ma, Z. et al., 2017. Dryland climate change: Recent progress and challenges. Reviews of Geophysics, 55(3), pp.719-778. DOI: https://doi.org/10.1002/2016RG000550

Hughes, S., 2012. Voluntary Environmental Programs in the Public Sector: Evaluating an Urban Water Conservation Program in California. Policy Studies Journal, 40(4), pp.650-673. DOI: https://doi.org/10.1111/j.1541-0072.2012.00468.x

Hurlimann, A. and Dolnicar, S., 2012. Newspaper coverage of water issues in Australia. Water research, 46(19), pp.6497-6507. DOI: https://doi.org/10.1016/j.watres.2012.09.028

Inskeep, B.D and Attari, S.Z., 2014. The water short list: The most effective actions US households can take to curb water use. Environment: Science and policy for sustainable development, 56(4), pp.4-15. DOI: https://doi.org/10.1080/00139157.2014.922375

Jacobs, K.L. and Holway, J.M., 2004. Managing for sustainability in an arid climate: lessons learned from 20 years of groundwater management in Arizona, USA. Hydrogeology Journal, 12(1), pp.52-65. DOI: https://doi.org/10.1007/s10040-003-0308-y

Kaika, M., 2003. Constructing scarcity and sensationalising water politics: 170 days that shook Athens. Antipode, 35(5), pp.919-954. DOI: https://doi.org/10.1111/j.1467-8330.2003.00365.x

Kasperson, R.E., Renn, O., Slovic, P., Brown, H.S., Emel, J., Goble, R., Kasperson, J.X. and Ratick, S., 1988. The social amplification of risk: A conceptual framework, Risk analysis, 8(2), pp.177-187. DOI: https://doi.org/10.1111/j.1539-6924.1988.tb01168.x

Kull, C.A., 2004. Isle of fire: the political ecology of landscape burning in Madagascar, University of Chicago press.

Kupel, D.E., 2003, Fuel for growth: Water and Arizona's urban environment, Tucson, University of Arizona Press.

Larson, K.L., Gustafson, A. and Hirt, P., 2009. Insatiable thirst and a finite supply: an assessment of municipal water-conservation policy in greater Phoenix, Arizona, 1980-2007, Journal of Policy History, 21(2), pp.107137. DOI: https://doi.org/10.1017/S0898030609090058

Lebart, L., Salem, A. and Berry, L., 1998. Exploring textual data, Kluwer Academic Publisher.

Lebart, L., Pincemin, B. and Poudat, C., 2019. Analyses des données textuelles, Presses de l'Université du Québec.

Leong, C., 2021. Narratives and Water: A bibliometric review. Global Environmental Change, 8, p.102267. DOI: https://doi.org/10.1016/j.gloenvcha.2021.102267 
887 Liang, Y., Henderson, L.K. and Kee, K.F., 2018. Running out of water! Developing a message typology and

888 evaluating message effects on attitude toward water conservation. Environmental Communication, 12(4),

889 pp.541-557. DOI: https://doi.org/10.1080/17524032.2017.1288648

890 Lloyd-Hughes, B., 2014. The impracticality of a universal drought definition. Theoretical and Applied

891 Climatology, 117(3), pp.607-611. DOI: https://doi.org/10.1007/s00704-013-1025-7

892 Lockwood, M., 2011. Does the framing of climate policies make a difference to public support? Evidence from

893 UK marginal constituencies. Climate Policy, 11(4), pp.1097-1112. DOI:

894 https://doi.org/10.1080/14693062.2011.579301

895 Logan, M.F., 1995. Fighting sprawl and city hall: Resistance to urban growth in the Southwest, University of

896 Arizona Press, Tucson.

897 Madruga de Brito, M., Kuhlicke, C. and Marx, A., 2020. Near-real-time drought impact assessment: a text

898 mining approach on the 2018/19 drought in Germany. Environmental Research Letters, 15(10), p.1040a9.

899 DOI: https://doi.org/10.1088/1748-9326/aba4ca

901 Maggioni, E., 2014. Water demand management in times of drought: What matters for water conservation.

902 Water Resources Research, 51(1), p.125-139. DOI:

903 https://doi.org/10.1002/2014WR016301

March, H., Domènech, L. and Saurí, D., 2013. Water conservation campaigns and citizen perceptions: the drought of 2007-2008 in the Metropolitan Area of Barcelona, Natural hazards, 65(3), pp.1951-1966. DOI: https://doi.org/10.1007/s11069-012-0456-2

Marpsat, M., 2010. La méthode Alceste. Sociologie, 1(1). URL :

http://journals.openedition.org/sociologie/312

Megdal, S.B. and Forrest, A., 2015. How a Drought-Resilient Water Delivery System Rose Out of the Desert: The Case of Tucson Water. JAWWA Journal-American Water Works Association, 107(9), pp.46-52. DOI: https://doi.org/10.5942/jawwa.2015.107.0136

Moglia, M., Cook, S. and Tapsuwan, S., 2018. Promoting water conservation: where to from here?

Water, 10(11), p.1510. DOI: https://doi.org/10.3390/w10111510

Molle, F., 2008. Nirvana concepts, narratives and policy models: Insights from the water sector. Water alternatives, 1(1), pp.131-156.

O'Neill, B., Cortinas, J., Coeurdray, M. and Poupeau, F., 2018. Reinventing Water Conservation. In Poupeau, F., Razafimahefa, L., Robert, J., Mercier, D., Massardier, G. and Jacobi P.R., eds., Water Conflicts and Hydrocracy in the Americas, University of Sao Paulo Press, p.293.

O’Neill, B.F. and Boyer, A.L., 2020. Water Conservation in Desert Cities: From the Socio-ecological Fix to Gestures of Endurance. Ambiente e Sociedade, 23. DOI: https://doi.org/10.1590/1809$\underline{4422 a s o c 20190069 \mathrm{r} 1 \mathrm{vu} 202011 \mathrm{ao}}$

929 Paneque Salgado, P. and Vargas Molina, J., 2015. Drought, social agents and the construction of discourse in 930 Andalusia. Environmental Hazards, 14(3), p.224-235. DOI: https://doi.org/10.1080/17477891.2015.1058739 
931 Parks, L., 2018. Challenging power from the bottom up? Community protocols, benefit-sharing, and the

932 challenge of dominant discourses. Geoforum, 88, pp.87-95. DOI:

933 https://doi.org/10.1016/j.geoforum.2017.11.011

934

935

936

937

938

939

940

941

942

943

944

945

946

947

948

Phoenix AMA, 1984. First Management Plan. URL:

http://infoshare.azwater.gov/docushare/dsweb/Get/Document-10006/1MP\%2019801990\%20Dec.1984.pdf

Phoenix AMA, 2016. Fourth Management Plan.

URL: http://infoshare.azwater.gov/docushare/dsweb/Get/Document-10007/PhoenixAMA_3MP.pdf

Poupeau, F., Gupta, H., Serrat-Capdevila, A., Sans-Fuentes, M.A., Harris, S. and Hayde, L.G., eds., 2016. Water bankruptcy in the land of plenty, CRC Press.

Quesnel, K.J. and Ajami, N.K., 2017. Changes in water consumption linked to heavy news media coverage of extreme climatic events, Science advances, 3(10), p.e1700784. DOI:

https://doi.org/10.1126/sciadv.1700784

Ratinaud, P., 2009. IRAMUTEQ: Interface de R pour les Analyses Multidimensionnelles de Textes et de Questionnaires. URL: http://www.iramuteq.org

Ratinaud, P. and Marchand, P., 2012. Application de la méthode ALCESTE à de "gros" corpus et stabilité des "mondes lexicaux": analyse du "CableGate" avec IRaMuTeQ. Actes des 11 eme Journées internationales d'Analyse statistique des Données Textuelles, pp.835-844. URL: http://lexicometrica.univparis3.fr/jadt/jadt2012/Communications/Ratinaud,\%20Pierre\%20et\%20al.\%20\%20Application $\% 20 \mathrm{de} \% 201 \mathrm{a} \% 20$ methode $\% 20$ Alceste.pdf

957 R Core Team, 2018. $R$ : A language and environment for statistical computing.

958 Reinert, A., 1983. Une méthode de classification descendante hiérarchique : application à l'analyse lexicale par 959 contexte. Cahiers de l'Analyse des Données, 8, pp. 187-198.

960 Reinert, M., 1990. Alceste une méthodologie d'analyse des données textuelles et une application:Aurelia De 961 Gerard De Nerval. Bulletin de méthodologie sociologique, 26, pp. 24-54.

962

963 Richardson, J., 2007. Analysing newspapers: An approach from critical discourse analysis, Palgrave.

964 Rinne, P. and Nygren, A., 2016. From resistance to resilience: media discourses on urban flood governance in

965 Mexico. Journal of Environmental Policy \& Planning, 18(1), pp.4-26. DOI:

966 https://doi.org/10.1080/1523908X.2015.1021414

Roe, E., 1994. Narrative policy analysis: Theory and practice, Duke University Press.

Ross, A., 2011. Bird on fire: Lessons from the world's least sustainable city, Oxford University Press.

Savenije, H. H. and Van Der Zaag, P., 2002. Water as an economic good and demand management paradigms with pitfalls. Water international, 27(1), pp.98-104. DOI: https://doi.org/10.1080/02508060208686982

Schipper, J., 2008. Disappearing desert: The Growth of Phoenix and the Culture of Sprawl, University of Oklahoma Press, Norman.

976 Sheridan, T.E., 2012. Arizona: A History, University of Arizona Press, Tucson. 
977 Smith, N., 1984. Uneven development: Nature, capital, and the production of space, University of Georgia 978 Press, Athens.

979

980

981

982

983

984

985

986

987

988

989

990

991

992

993

994

995

996

997

998

999

1000

1001

1002

1003

1004

1005

1006

1007

1008

1009

1010

1011

1012

1013

1014

1015

1016

1017

1018

1019

1020

1021

1022

1023

1024

Sonnett, J., Morehouse, B. J., Finger, T. D., Garfin, G. and Rattray, N., 2006. Drought and declining reservoirs: Comparing media discourse in Arizona and New Mexico, 2002-2004. Global Environmental Change, 16(1), pp. 95-113. DOI: https://doi.org/10.1016/j.gloenvcha.2005.11.004

Spencer, J.W. and Triche, E., 1994. Media constructions of risk and safety: Differential framings of hazard events. Sociological Inquiry, 64(2), pp.199-213. DOI:

https://doi.org/10.1111/j.1475-682X.1994.tb00388.x

Svarstad, H. and Benjaminsen, T.A., 2017. Nothing succeeds like success narratives: A case of conservation and development in the time of REDD. Journal of Eastern African Studies, 11(3), pp.482-505. DOI: https://doi.org/10.1080/17531055.2017.1356622

Swyngedouw, E., Page, E. and Kaïka, M., 2002. Sustainability and Policy Innovation in a Multi-Level Context: Crosscutting Issues in the Water Sector. In Heinelt, H., Getimis, P., Kafkalas, G., Smith, R. and Swyngedouw, E., Participatory Governance in Multi-Level Context: Concepts and Experience, Leske and Budrich, Opladen, p. 107-131.

Swyngedouw, E., 2011. Whose environment?: the end of nature, climate change and the process of postpoliticization. Ambiente \& sociedade, 14(2), pp. 69-87. DOI: https://doi.org/10.1590/S1414$\underline{753 \times 2011000200006}$

Swyngedouw, E., 2013. Into the sea: desalination as hydro-social fix in Spain. Annals of the Association of American Geographers, 103(2), pp.261-270. DOI: https://doi.org/10.1080/00045608.2013.754688

Tänzler, D., Feil, M., Krömker, D. and Eierdanz, F., 2008. The challenge of validating vulnerability estimates: the option of media content analysis for identifying drought-related crises. Regional Environmental Change, 8(4), pp.187-195. DOI: https://doi.org/10.1007/s10113-008-0064-6

Tucson AMA, 1984. First Management Plan. URL: http://infoshare.azwater.gov/docushare/dsweb/Get/Document-10008/1MP\%201980-1990.Dec.1984.pdf

Tucson AMA, 2016, Third Management Plan. URL: http://infoshare.azwater.gov/docushare/dsweb/Get/Document-10038/TAMA_4MP_Complete.pdf

USBR, 2021. 24-Month Study Report, May 2021. URL: http://usbr.gov/uc/water/crsp/studies/24Month_05.pdf US. Census, 2019, Fastest-Growing Cities Primarily in the South and West. URL: https://www.census.gov/newsroom/press-releases/2019/subcounty-population-estimates.html

Vickers, A., 2017. Drought Mitigation: Water Conservation Tools for Short-Term and Permanent Water Savings. In Wilhite, D. and Pulwarty, R.S., eds., Drought and Water Crises: Integrating Science, Management, and Policy, CRC Press, p.307.

Wakefield, S.E. and Elliott, S.J., 2003. Constructing the news: The role of local newspapers in environmental risk communication. The Professional Geographer, 55(2), pp.216-226. DOI: https://doi.org/10.1111/0033$\underline{0124.5502009}$

Wei, J., Wei, Y., Western, A., Skinner, D. and Lyle, C., 2015. Evolution of newspaper coverage of water issues in Australia during 1843-2011. Ambio, 44(4), pp.319-331. 
1025

1026

1027

1028

1029

1030

1031

1032

1033

1034

1035

1036

1037

1038

1039

1040

1041

1042

1043

1044

1045

1046

1047

1048

1049

1050

1051

1052

1053

1054

1055

1056

1057

1058

1059

1060

1061

1062

1063

1064

1065

1066

1067

1068

1069

1070

1071

1072

1073

Wilhite, D.A. and Glantz, M.H., 1985. Understanding: the drought phenomenon: the role of definitions. Water international, 10(3), pp.111-120. DOI: https://doi.org/10.1080/02508068508686328

Wilhite, D. and Pulwarty, R.S., eds., 2017. Drought and water crises: integrating science, management, and policy, CRC Press.

Wilkins, L. and Patterson, P., 1990. Risky business: Covering slow-onset hazards as rapidly developing news. Political Communication, 7(1), pp.11-23. DOI: https://doi.org/10.1080/10584609.1990.9962884

WMO, 2016. Handbook on Drought Indicator and Indices, Integrated Drought Management Program (IDMP), Integrated Drought Management Tools and Guidelines Series 2, Geneva, Switzerland. URL: https://library.wmo.int/doc num.php?explnum id=3057

WMO, 2020. State of the Global Climate 2020, Provisional Report, Geneva, Switzerland. URL: https://library.wmo.int/doc_num.php?explnum_id=10444

Worster, D., 1985. Rivers of empire: Water, aridity, and the growth of the American West, Oxford University Press.

Wutich, A., White, A.C., White, D.D., Larson, K.L., Brewis, A. and Roberts, C., 2014. Hard paths, soft paths or no paths? Cross-cultural perceptions of water solutions. Hydrology and Earth System Sciences, 18(1), pp.109-120. DOI: https://doi.org/10.5194/hess-18-109-2014

\section{List of figures}

Figure 1: A sign provided by Tucson water utility indicating the use of reclaimed water to irrigate this property in the Sam Hughes neighborhood (Photo by first author, May 2018).

Figure 2: Study area: Phoenix and Tucson in the Lower Colorado River Basin.

Figure 3: Distribution of published articles tackling drought and water issues in the Arizona Daily Star and Arizona Republic between 1999 and 2018.

Figure 4: Evolution of the occurrences of "conservation" and "save" in the corpus, 1999-2018.

Figure 5: Clustering tree after a top-down hierarchical clustering on The Arizona Daily Star and the Arizona Republic (1999-2018) performed with IRaMuTeQ according to the Alceste Method (Reinert, $1983 ; 1990)$. The percentage correspond to the \% of text segments contributing to form each cluster. Words are ranked according to their $\mathrm{Chi}^{2}$ values, from the highest scores on top of the list to the lowest.

Cap= Central Arizona Project; buschatzke = Arizona Department of Water Resources' Director (2015-); norton= Secretary of Interior (2001-2006); connor= Deputy Secretary of the Department of Interior (2014-2017); cooke= CAP's general manager (2016-); napolitano= Arizona Governor (2003-2009).

Figure 6: List of actors mentioned more than 100 times in the corpus. ducey= Arizona Governor (2015-)

Figure 7: Graph of the similarity analysis based on cluster 6, dealing with water conservation (see Figure 5). A similarity analysis allows us to better understand the lexical world of water conservation. The thickness of the line is function of the words co-occurrences. The font size is determined by the word frequency. napolitano = Arizona Governor (2003-2009). 
1074

1075

1076

1077

1078

1079

1080

1081

1082

1083

1084

1085

1086

1087

1088

1089

1090
Figure 8: Xeriscape Demonstration Garden in Glendale (Phoenix Metro Area) (Photo by first author, June 2018).

\section{List of tables}

Table 1: Cooccurrences of the lemma "conservation". The co-frequency is the number of encounters that occur between the co-occurrents and the occurrences of the query. The co-occurrence score is an indicator determining the probability of association. The mean distance indicates the physical distance between two words. For example, in the text, the word "reuse" is often more than 2.5 words away from the word "conservation". 